\title{
REFLECTING ON HOSPITALITY STUDENTS' COGNITIVE DIVERSITY IMPACT ON SERVICE QUALITY AND ORGANIZATIONAL PERFORMANCE STANDARDS: A CASE-STUDY IN CY SEASONAL HOTELS
}

\author{
Michael Anastasiou \\ Faculty of Hospitality Management and Culinary Arts, InterNapa College, Cyprus \\ michael.anastasiou@gmail.com
}

\begin{abstract}
This study examines the impact of hospitality students' cognitive diversity style on service quality and performance standards in seasonal hotels. A survey research method approach was implemented through a quantitative examination of a purposeful sample, collected from three-, four-, and five-star seasonal hotels in Cyprus. The survey was administered face-to-face to 316 students and 93 managers. For hypotheses testing, the Cognitive Style Inventory was adapted. Study results reveal students' educational preparedness, professional reliability, and the positive impact of their cognitive diversity style on service quality and organizational performance standards in seasonal hotels. While students offer a diversified pool of potential candidates to successfully fulfil qualified and skilful required vacancies, a twofold requirement emerges. First is the introversion requirement related to the curriculum design of hospitality educational institutions. Second is the extroversion requirement, which sees the responsibility of seasonal hotel managers, as future employers, to be linked and guided on students' cognitive style development via an intuitive collaboration with local hospitality educational institutions.
\end{abstract}

Keywords: Service Quality Standard; Cognitive Diversity Impact; deep-level workforce diversity

\section{INTRODUCTION}

The globalized business arena, intense labour mobility, and immigrant flows have led to workforce diversity's emerging reality (Young \& Tackett, 2018). As a result, research on diversity management is evolving in various hospitality contexts and settings in efforts to improve responsiveness to guests' expectations and operational standards (Gröschl, 2011; B. P. Kim, Murrmann, \& Lee, 2009; Pinar, McCuddy, Birkan, \& Kozak, 2011; Sourouklis \& Tsagdis, 2012). In the hotel management literature, the concept of diversity has been examined; basically, on two different levels. The first is the surface-level diversity that concerns primary differences among individuals (Goh \& Okumus, 2020; Song, Yoon, \& Kang, 2020). The second concerns the deep-level or cognitive diversity style that includes individuals' variations in terms of skills and competencies, knowledge, cognitive styles, beliefs, and values (Shin, Kim, Lee, \& Bian, 2012). Although both levels 
have been found as performance and creativity drivers, the majority of the findings from empirical research in the hotel management literature remain limited with respect to surface-level workforce diversity. Hence, the opinions on deep-level diversity remain opposed (Menold \& Jablokow, 2019; Tekleab \& Quigley, 2014). This major gap in the literature was observed due to the direct applicability of the concept of cognitive diversity style to hotels' multi-task working environment, making imperative the need for further investigation in order to understand its contribution to service quality and performance in seasonal hotels.

There are a plethora of studies in the hotel management literature that focus mainly on workforce diversity from its socio-cultural, ethnocentric perspective and its primary characteristics (Manoharan, Sardeshmukh, \& Gross, 2019; Manoharan \& Singal, 2017). However, no research exists concerning the impact of higher education hospitality students' cognitive diversity style on service quality and organizational performance standards of seasonal hotels. At an academic level, higher education institutions, as professional and skills development incubators, need to be aware of the dimension of cognitive diversity in curriculum design for advancing teaching and internship purposes (Anastasiou \& Koumi, 2019). On the other hand, hotel managers, from an industry perspective, could fulfil departmental job vacancies with hospitality management students in maintaining the consistency of service quality and organizational performance standards. By understanding in what ways hospitality students' cognitive diversity dynamics may affect service quality and organizational performance standards in seasonal hotels, hospitality educators and managers could improve students' career prospects and upgrade the quality of their internships or part-time employment. The current research inquiry extends the literature by building awareness on what elements of hospitality students' cognitive diversity style contribute towards seasonal hotels' service quality and performance standards.

\section{Literature Review}

The tourism and hospitality sector intrinsically depends on various direct or indirect stakeholders who work, contribute to, or influence the industry in different ways (Baum, Kralj, Robinson, \& Solnet, 2016). Among the industry, influencers are the hospitality and tourism management higher education institutions and their graduates, who stimulate and influence the industry's future workforce development. As professional development venues, the educational institutions educate and prepare skilful, competent, and qualified graduates by offering cuttingedge and diversified programme curricula (Anastasiou \& Koumi, 2019). Such dynamic curricula emerge from a serious industry labour need, due to stakeholders' operational span from ownership, employment, and service variations to standards, policies, and procedures. Hence, the industry's forecasts predict new and diversified job openings, requiring well-educated and trained hospitality professionals (Australia Hotel Association, 2015; Deloitte, 2015, 2017; World Travel \& Tourism Council, 2017). Although the industry's global growth predictions are very promising, its stakeholders fail to keep hospitality graduates motivated to continue in the field (Goh \& Lee, 2018).

Researchers such as Duro \& Turrión-Prats (2019) and Ferrante et al. (2018) indicate that the competitive business environment intensifies even more the subtleties of the industry's nature, including major sustainability and seasonality 
variables. The latter has been extensively examined due to its strong relation to service quality and organizational performance standards deviation (Chalkiti \& Sigala, 2010; Goh \& Lee, 2018). Furthermore, the observed seasonality problems and the high demand for labour in a relatively short period of time enabled easy labour entrance to individuals with no hospitality educational background or related professional skills to the hotel industry (Anastasiou \& Koumi, 2019). Additionally, the high seasonal workforce mobility and employee turnover rate, different workforce management implications along with the shortage of a competent professional workforce were found to be sources that keep leading to serious service quality and organisational performance standards gaps in seasonal hotels (Sourouklis \& Tsagdis, 2012).

As a result, hospitality practitioners and recruiters need to examine the quality and the responsiveness of hospitality students' cognitive diversity style and its potential professional quality in a multi-task working context such as a hotel's working environment. Hospitality students may be an optimal solution and a transformational vehicle in seasonal hotel operations that equalises quality and performance imbalances caused by other types of seasonal employees (Cox \& Blake, 1991; Menold \& Jablokow, 2019). Thus, the recruitment of hospitality students could create a workforce, a homogenised driver in hotel operations that, under the talent-based umbrella, could sustain operational infusion with diversified and heterogeneous working groups, securing thus creativity, service quality, and performance standards (Hoever, van Knippenberg, van Ginkel, \& Barkema, 2012).

\section{Surface-level diversity}

Important operational parameters such as the industry's geographical widespread, pure service orientation, and labour intensity in relation to high seasonal employment turnover rate intensify the operational implications emerging from workforce diversity in seasonal hotels (Hsiao, Ma, \& Auld, 2014; Pegg, Patterson, \& Gariddo, 2012). Such implications go beyond the usual and wellknown surface-level workforce diversity dynamics that are encountered primarily in ethnographic and demographic characteristics. As proof, findings from empirical research oppose two contradictory arguments about surface-level workforce diversity in hotels. The first argument posits that personal characteristics of individuals or groups were found as a source of degrading intra-organisational operational consistency at all levels, easing social loafing and personal bias due to barriers in communication, ethnocentric prejudice, rejection, diffusion, and delusion (Anglim, Sojo, Ashford, Newman, \& Marty, 2019). As a result, organisational and operational dysfunctions may occur due to employees' sociopsychological background, weak feelings of organisational citizenship, inappropriate personal habits, and unprofessional attitudes (Hight, Gajjar, \& Okumus, 2019; Tufan \& Wendt, 2020). Such complex challenges seriously affect organisational cohesiveness and quality teamwork in anticipating and responding to guests' unpredictable requests (Hanaysha, 2016), particularly at seasonal hotels. As a result, modernised hotel organisations are enforced to proactively embrace the dimensions of workforce diversity in order to sustain operational responsiveness and secure further development (Anglim et al., 2019).

Although observed intense labour mobility, foreign investment, and international competition magnify issues emerging from diversity in the workplace, 
the second argument posits that workforce diversity may derive reputational outcomes and performance achievements (Singal, 2014; Wang, Kim, \& Lee, 2016). Researchers such as Manoharan et al. (2019), McMahon (2011), Menold \& Jablokow (2019), and Singal (2014) identify in their studies a positive and strong link between workforce diversity and organisational performance. This link highlights a particular effect on service-oriented industries due to employees' interpersonal interactions and personalised guest service requests. Both elements are tightly connected to the capability of a hotel organisation to innovate and differentiate operationally by infusing cutting-edge technologies and advancing the capability of the firm's human capital to perform complicated job tasks and duties.

Although arguments and beliefs about surface-level diversity are well documented, for both arguments, there is a serious ignorance concerning the effects of deep-level diversity on service quality and performance standards (Menold \& Jablokow, 2019; Sauer, Felsing, Franke, \& Rüttinger, 2006). Complicated and collective job tasks and duties are central to daily hotel operations, altering the need to understand that a deeper level of workforce diversity may be a highly influential dynamic. Notwithstanding, there is sufficient availability of hospitality students for internships and part-time jobs as a rich pool of strong cognitive diversity in order to contribute towards hotel operational effectiveness.

\section{Deep-level diversity}

Cognitive diversity style, a deep-level diversity, as a new term in the hotel management literature calls for a comprehensive reconceptualisation of workforce diversity management approaches and emerging implications in hotel operations. The multicultural business environment of the hospitality industry should ignore the monolithic perception concerning the dynamics and management of workforce diversity in a vacuum. Progressive and operational performance drivers related to personal virtues, such as emotional labour, self-esteem and actualisation, dedication, and sense of belongingness (H. J. Kim \& Agrusa, 2011; Wen, Huang, \& Hou, 2019), alter the personal cognitive style as a complementary parameter to deep-level diversity, which may effectively contribute to service quality and organisational performance. In the hotel industry, for example, a huge number of diverse work positions requiring high or low specialisation skills compose the service delivery process, increasing the implications from service variations and guests' unpredictable requests, expectations, and quality standards (Anastasiou \& Koumi, 2019).

\section{Conceptual Framework.}

In the current research inquiry, the conceptual framework [Figure 1] posits that hospitality students' cognitive diversity could positively contribute to service quality and performance standards in seasonal hotels. Hence, the shortage of a qualified and competent workforce observed in the Cypriot hotel industry (CEDEFOP, 2019; Financial Mirror, 2019a, 2019b; Hadjioannou, 2019; Kathimerini, 2018; KPMG, 2019) would be eliminated. In the post-bail-in period and the deep economic recession that Cyprus went through, beginning in March 2013, a need arose for the government to rethink and reinvest in the hospitality and tourism industry. As a micro-tourism destination and economy, the Cypriot government reflected on the positive impacts and considered the different short- 
and long-term benefits emerging from the industry's economic and social multiplier effect (Caribbean Tourism Performance, 2017; Financial Mirror, 2019a, 2019b; Hadjioannou, 2019; KPMG, 2019) (Financial Mirror, 2019a, 2019b; KPMG, 2019).

Figure 1: Conceptual framework
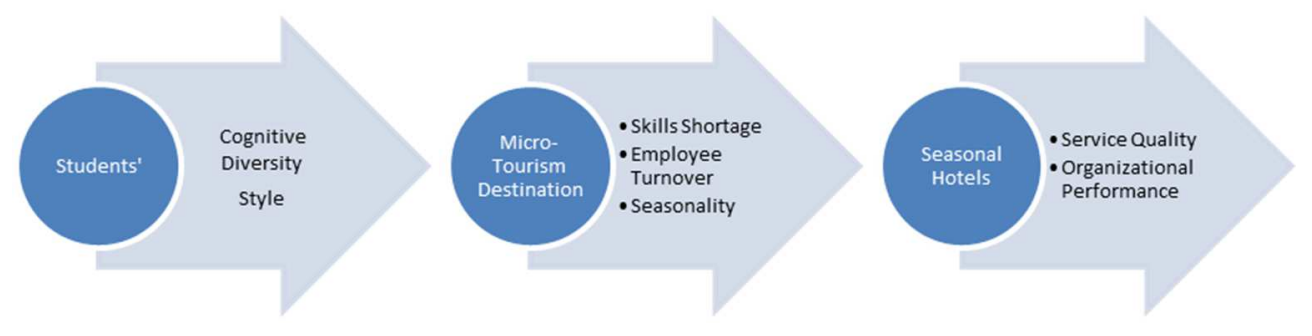

Although the local unemployment rate was drastically decreased and new job openings re-energised the local hotel industry (Hadjioannou, 2019), a shortage of competent and qualified hotel employees was observed, resulting in serious and noticeable service quality gaps and operational and performance problems in the hotel sector (Kathimerini, 2018). Unsurprisingly, the lack of a smooth transition from the intense economic recession to economic progress and development of the hotel industry forced business recruiters to recruit on demand, ignoring candidates' prior relatedness to the hotel industry. As a consequence, underestimation of the current circumstances emerged dynamics of cognitive diversity implications, and workplace multiculturalism issues led to operational inconsistencies, ineffectiveness and inefficiencies in seasonal hotels (Brevis \& Vrba, 2015; Strydom \& Fourie, 2018). Simultaneously, the growth rate and progressive role of hospitality higher education institutions on the island stresses the lively contribution of students during an internship or part-time employment.

Students in this research inquiry are defined as individuals studying hospitality and tourism-related specialisations in higher education in private or public colleges and universities. Accordingly, cognitive diversity style is specified as the sum of individuals' variations and backgrounds in terms of skills, professional knowledge, thinking styles, decision-making and problem-solving competencies, beliefs, and values (Shin et al., 2012). Hotel managers and supervisors were defined as key participants in the study with a responsibility to oversee day-to-day duties and supervise and interact with the recruited hospitality students. Seasonal employees are specified as individuals moving to a tourist destination for a summer season with no background in hospitality education. Last, seasonal hotels are organisations operating during the summer season only.

The aim of the current research is to extend the literature in understanding how management hospitality students' cognitive diversity style could contribute to seasonal hotels' service quality and organisational performance standards. The Cognitive Style Inventory was selected in exploring the hospitality students' cognitive diversity for four major reasons (Martin, 1982). The first reason was to raise the industry stakeholders' awareness of the significance of hospitality students' cognitive diversity in hotel operations and standards. The second was to understand how new skills, competencies, and other cognitive styles developed by students in hospitality schools could assist in improving personal effectiveness in facilitating problem-solving and decision-making. The third reason was to detect 
any personal commonalities in an effort to create synergies in the workplace. The last reason was to examine the hospitality students' contribution to seasonal hotels in becoming learning organisations.

\section{Hypothesis Testing}

A survey research strategy was implemented in order to collect data and test hypotheses of the relationship between students' cognitive diversity style and its impact on seasonal hotels' service quality and organisational performance standards. Specifically, this research inquiry was designed in order to understand how hospitality students' cognitive styles may affect service quality and performance standards when fulfilling job vacancies in seasonal hotels, in part-time mode or during summer internships. Subsequently, it could be determined if the effect of students' cognitive diversity on service quality and organisational performance standards could lead to effectively fulfilling major job vacancies in seasonal hotels in the case of a summer internship or part-time employment. As a result, conclusions may be drawn as to whether or not hospitality students can effectively fulfil open professional vacancies during internships or part-time employment over seasonal employees. This interrelationship and the emerging hypotheses are illustrated in Figure 2. Six hypotheses were proposed to testify research findings and determine the effect of hospitality students' cognitive diversity on service quality and performance standards in seasonal hotels:

- Hypothesis 1a. Hospitality students' cognitive diversity style affects positively service quality standards in seasonal hotels.

- Hypothesis 1b. Hospitality students' cognitive diversity style affects positively organisational performance standards in seasonal hotels.

- Hypothesis 2. Hospitality students' cognitive diversity style is of a certain professional standard that makes hospitality students capable of effectively fulfilling job vacancies in seasonal hotels.

- Hypothesis 3. Hospitality students' cognitive diversity style makes them more reliable over seasonal employees fulfilling more effectively job vacancies in seasonal hotels.

- Hypothesis 4. Hospitality students' acquired skills, competencies, and other cognitive styles developed in hospitality schools could assist in improving personal effectiveness in facilitating problem-solving and decision-making in seasonal hotels.

- Hypothesis 5. Hospitality students have personal commonalities that help in creating synergies and innovative approaches in the workplace.

- Hypothesis 6. Hospitality students may contribute to seasonal hotels becoming learning organisations.

Figure 2: Conceptual research model

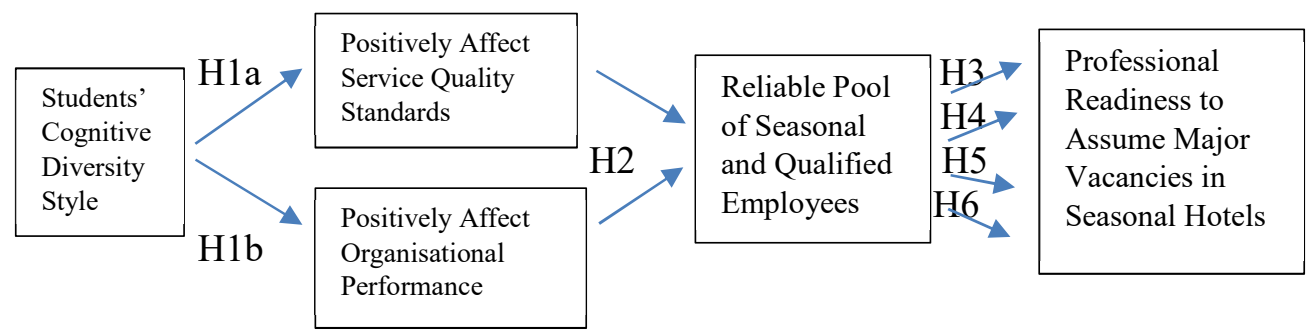




\section{Data Collection, Processing, and Analysis.}

The survey research strategy was used to collect large amounts of data via questionnaire (Discroll et al., 1994; Leach, 1996; Thompson, 2001), eliminating any bias, cues, or guiding that may affect the validity or the reliability of the findings (Cresswell, 2002; Nardi, 2002). This quantitative research technique allowed the penetration, through their thoughts, of the perceptions, opinions, and beliefs of hospitality students and hotel managers and supervisors concerning the impact of hospitality students' cognitive diversity style on service quality and performance standards of seasonal hotels. The study was conducted in seasonal hotels operating in the four coastal districts of the Republic of Cyprus. All seasonal hotels were selected from the Cyprus Tourism Organisation directory, fulfilling all legal prerequisites or core requisites to operate legally during summer seasons. Seasonal hotels were selected because they represent the operational and economic backbone of the local hotel industry, being highly related to the recruitment of hospitality students for internship purposes, as an option in fulfilling job vacancies.

A major hotel selection criterion was that participant hotel enterprises were operating on a seasonal basis during the last five years. This reason was based on the work of Kotey \& Slade (2005) and Manoharan et al. (2019) who suggested in their empirical research that medium-size companies tend to implement more informal approaches in managing human resources and workforce. Hence, due to seasonality, the seasonal recruitment of employees is becoming a serious operational obstacle in securing expected service quality and performance standards (Hadjioannou, 2019; Kathimerini, 2018). The data was collected through face-toface interviewer-administered questionnaires. All participants were asked to evaluate the adapted 40 statements of the Cognitive Style Inventory (CSI) in order to be classified according to their cognitive style.

\section{Survey instrument: Cognitive Style Inventory.}

In order to test the current research's hypotheses, the CSI was adapted as an instrument to assess the contribution of hospitality students' cognitive diversity level to service quality and performance standards of seasonal hotels. The pursuit of this effort was to understand the correlation between students' and managers' opinions concerning the students' personal cognitive diversity style and how it responds to the individual, group, and organisational dynamics. Early research theories (Bruner, 1966; Witkin, Dyk, Patterson, Goodenough, \& Karp, 1962; Witkin et al., 1951) and recent empirical evidence (McKenney \& Keen, 1974; Mowforth \& Munt, 1997) concerning cognitive style and behaviours underline the importance of quantitative and qualitative behavioural cognition in individuals' learning and thinking as well as on decision-making and problem-solving ability, as well as personal and professional qualities that may boost individual, team or organizational growth, performance and productivity. In the current study, the use of the adapted form of the CSI (Martin, 1982) had a twofold purpose. The first was aimed at understanding the organisational benefits from hospitality students' cognitive style and behavioural signs related to their capabilities for problemsolving, learning, and thinking. The second aimed to build awareness concerning developmental strategies in order to increase individuals' cognitive capacity and skills (at college or hotel level) for positive impact on service quality and performance. 
The tool-assisted in examining five personal cognitive styles: a) systematic, b) integrated, c) undifferentiated, d) intuitive, and e) split. As a research instrument, it created the conditions to compare two extreme rankings of the variables defined in Table 1 , using from negative $(1=$ Strongly Disagree $)$ to positive values $(5=$ Strongly Agree), and comparing the cognitive styles that hospitality students may assume during internships or part-time jobs. For instance, the CSI examines the effects on individuals, groups, and organisations by detecting any possible blind spots that may distract an individual's effectiveness in fitting, matching, or contributing to teamwork, synergies, tasks, and jobs in a way that affects service quality and performance standards in hotels (Martin, 1982).

Although the CSI's use was limited to its actual purpose to measure the cognitive style of individuals, a pilot study was deployed for the current study in order to reconfirm the reliability, validity, appropriateness, and accuracy (Yin, 2017) of the adapted statements. The adapted statements changed from 'I generally rely on facts and data when problem-solving' (Martin, 1982, p. 14) to 'I generally rely on facts and data when problem-solving related to service quality issues' and 'Students generally rely on facts and data when solving problems related to service quality issues', for students and managers respectively. The CSI was tested with 20 students and ten managers, in order to ensure that all no participants would not have issues in understanding and answering the instrument's questions.

\section{Table 1: Cognitive style definition}

\begin{tabular}{ll}
\hline Cognitive Style & \multicolumn{1}{c}{ Definition } \\
\hline Systematic & $\begin{array}{l}\text { This reflects rational behaviour and a more logical and } \\
\text { sequential tactic towards an effective individual or group } \\
\text { decision-making, problem-solving, learning and thinking }\end{array}$ \\
\hline Intuitive Style. & $\begin{array}{l}\text { This refers to holistic and spontaneous methods in the } \\
\text { process of making decisions. }\end{array}$ \\
\hline Undifferentiated & $\begin{array}{l}\text { It defines individuals who pose withdrawn and passive } \\
\text { intentions, looking to others for decisions and problem- } \\
\text { Style. }\end{array}$ \\
solving.
\end{tabular}

The pilot study revealed no significant issues. Finally, the CSI was handed out to hotel managers and students during the academic year 2018/2019. A purposive sampling technique was used to collect the needed data from the seasonal three-, four-, and five- star seasonal hotels. The survey was administered face-toface administered to 417 students and 112 managers. In the case of students and after discounting 101 incomplete questionnaires, 316 were found to be consistent and valid. The recovery rate was $75.8 \%$. The recovery rate for the managers' sample was $83 \%$. Then, numerical codes were used in order to be organized and used for computer analysis in SPSS. Data analysis was completed in two stages. 
During the first stage, the goal was to profile hospitality students' cognitive style by measuring the five variables at an individual level, and before the findings were aggregated. Then, the instrument's variables were calculated using the withingroup inter-rater agreement (rwg) along with the inter-member reliability (ICC(1); ICC(2)) for the five variables [Table 2]. The test analysis met reliability levels, confirming the agreement obtained in previous research (Farh, Lee, \& Farh, 2010; Wang et al., 2016). After, and following the confirmation, individual responses were aggregated to team- level responses. This afforded an opportunity to understand the perceptions of hospitality management students versus hotel managers' opinions, concerning the relation of hospitality management students' cognitive diversity style to service quality and performance standards in seasonal hotels. In the second stage, a statistical analysis approach was adopted in testing the hypotheses of the current study.

Table 2: Emerging values from the within-group inter-rater agreement and the inter-member reliability

\begin{tabular}{ll}
\hline Cognitive Style & Values \\
\hline Intuitive & $r_{\mathrm{wg}}=.85, \operatorname{ICC}(1)=.17, \operatorname{ICC}(2)=.64$ \\
\hline Integrated & $r_{\mathrm{wg}}=.84, \operatorname{ICC}(1)=.22, \operatorname{ICC}(2)=.63$ \\
\hline Systematic & $r_{\mathrm{wg}}=.87, \operatorname{ICC}(1)=.25, \operatorname{ICC}(2)=.59$ \\
\hline Undifferentiated & $r_{\mathrm{wg}}=.82, \operatorname{ICC}(1)=.19, \operatorname{ICC}(2)=.48$ \\
\hline Split & $r_{\mathrm{wg}}=.86, \operatorname{ICC}(1)=.20, \operatorname{ICC}(2)=.67$ \\
\hline
\end{tabular}

\section{RESULTS AND DISCUSSION}

In order to test the hypothesis of the study, hierarchical linear modelling analysis was used in interpreting the multi-level nature of collected data, considering the vital role of students as individuals contributing to seasonal hotels' organisational standards. In the analysis, an intercept-only model approach was adopted at an organisational level due to the origin of the students and managers sample from different organisations. This allowed the control of confounding effects of company-level factors on the study's testified relationships and hypotheses. As a result, the effect of hospitality students' cognitive style on service quality and organisational performance standards via summer internships was tested using the 'product coefficient' approach suggested by MacKinno, Lockwood and Williams (2004; Table 3).

For this reason, a bootstrap sampling method was used to discover any asymmetric confidence intervals (CIs) and determine any indirect effects (Rousselet, Pernet, \& Wilcox, 2019; Sobel, 1982). According to Rousselet et al. (2019), the bootstrap CIs are based on data-driven simulations for statistical inferences, within which CIs are created aiming at two outcomes. The first is to develop more accurate estimations from the collected data, and, secondly, to yield asymmetric CIs based on the individual distribution of two regression coefficients of the examined variables (MacKinno et al., 2004). The statistical analysis was completed by testing the stage moderation mediation effect, suggested by Edwards \& Lambert (2007) in integrating the findings and parameters into reasonable expressions and explanations of a particular condition. 
Table 3: Comparison of the frequencies of the number of hospitality students and managers' sample

\begin{tabular}{|c|c|c|c|c|c|c|}
\hline $\begin{array}{l}\text { Cognitive } \\
\text { Style }\end{array}$ & Students & & Managers & & Difference & $\begin{array}{l}\text { Kolmogorov-Smirnov } \\
\text { Significance of } 5 \%\end{array}$ \\
\hline & $\begin{array}{l}\text { Aggreg. } \\
\text { Value }\end{array}$ & $\%$ & $\begin{array}{l}\text { Aggreg. } \\
\text { Value }\end{array}$ & $\%$ & $\%$ & \\
\hline Intuitive & 54 & 17.09 & 21 & 18.75 & -1.66 & $\begin{array}{c}\text { Maximum difference: } \\
2.38 \%\end{array}$ \\
\hline Integrated & 53 & 16.77 & 19 & 16.96 & -0.19 & Two-Sample K-S Test \\
\hline Systematic & 36 & 11.39 & 15 & 13.39 & -2.00 & $\begin{array}{c}0.72 / \sqrt{ } \text { of } n(112)= \\
0.01042\end{array}$ \\
\hline Undifferen. & 11 & 3.48 & 4 & 3.57 & -0.09 & $\begin{array}{c}\text { Contrast Statistic }= \\
6.80 \%\end{array}$ \\
\hline Split & 142 & 44.94 & 53 & 47.32 & -2.38 & $2.38<6.80 \%$ \\
\hline
\end{tabular}

Also, by following the comparison of the frequencies of the number of hospitality students and managers' sample, descriptive statistics were performed in order to appraise data variations between students and managers' responses within the context of the CSI. Means and standard deviation tests were performed, as illustrated in Table 4, indicating that the low standard deviation is clustered around the sample population mean. Thus, the normality of the collected data was assessed by the Shapiro-Wilk test of normality. The major reason was to determine what kind of parametric or non-parametric tests would be used in examining the study variables. The test revealed a non-parametric $(p<0.05)$ answer distributions. As a result, students and managers' responses were non-normal, leading to the use of Wilcoxon, Mann-Whitney U and Kruskal-Wallis tests.

The Mann-Whitney test was applied to students and managers' responses in order to examine their opinion on how their cognitive diversity style contributes to service quality in seasonal hotels. The statistical interpretation indicated a dominant tendency of the split cognitive style in service quality and performance standards. Therefore, the emerging values were examined to determine the direction of the calculated differences in the participants' responses as a Mann-Whitney test, as a non-parametric test, tests the main differences in mean and median values [Table $5]$.

Table 4: Cognitive Style Responses - Students and Managers' Descriptive Statistics

\begin{tabular}{lcccc}
\hline \multicolumn{1}{c}{$\begin{array}{c}\text { Students' } \\
\text { Response }\end{array}$} & Mean & St. Dev. & Mean & St. Dev. \\
\hline Systematic Style. & 2.67 & 0.68 & 2.77 & 0.69 \\
\hline Intuitive Style. & 2.84 & 0.73 & 2.97 & 0.77 \\
\hline Undiffer. Style. & 1.01 & 0.51 & 0.99 & 0.52 \\
\hline Integrated Style. & 2.74 & 0.72 & 2.99 & 0.78 \\
\hline Split Style. & 3.33 & 0.82 & 3.31 & 0.84 \\
\hline
\end{tabular}


Therefore, a cross-tabulation and a chi-square test were used on students and managers' responses and showed a strong common trend between the two groups of participants, concerning the split cognitive styles. This was actually a recognition from both groups of the impact of students' self-motivation and self-efficacy drive and dedication to career commencement in the industry. Also, the Kruskal-Wallis test was used to examine any particular differences in their responses, among students and managers. Both groups pinpointed the split cognitive style as a major individuality and professional characteristics umbrella that covers a major students' cognitive and competencies canvas, enhanced with personality and skill talents, which emerges from the infusion of intuitive and systematic cognitive styles. Moreover, after performing a cross-tabulation and a chi-square test, this tendency was explained as the individual commitment to service quality and, thus, the conscious pursuit of higher performance for achieving personal goals and career aspirations.

Table 5: Mann-Whitney test for statistical differences: Students vs managers' opinions about students' cognitive style diversity, with reference to service quality standards in seasonal hotels

\begin{tabular}{lcccc}
\hline & \multicolumn{2}{c}{ Students } & \multicolumn{2}{c}{ Managers } \\
\hline & Mann-Whitney & p-value & Mann-Whitney & p-value \\
\hline Systematic Style. & 92.2 & 0.02 & 93 & 0.023 \\
\hline Intuitive Style. & 91.5 & 0.015 & 92.3 & 0.018 \\
\hline Undiffer. Style. & 72.5 & 0.002 & 73.3 & 0.005 \\
\hline Integrated Style. & 89.9 & 0.009 & 90.7 & 0.012 \\
\hline Split Style. & 93.7 & 0.022 & 94.5 & 0.025 \\
\hline
\end{tabular}

Furthermore, using the undifferentiated cognitive style as a grouping variable, the nominal data were examined by using a chi-square test, whereas the ordinal data was examined by the Mann-Whitney test. Significant differences were found regarding passive personal and professional behaviour, strong focus on instructions, procrastination, and delays in actions and reactions. A further examination of the collected data was performed using the Kruskal-Wallis test in order to identify any differences according to the integrated cognitive style. The test revealed significant trends concerning the students' dual cognitive specialists' dimensions, the professional qualities of flexibility and adaptability, as well as their capability to innovate and solve problems $(\mathrm{p}<0.05)$.

\section{Hypothesis and reliability testing}

A reliability analysis of the groups' responses concerning the five cognitive diversity styles presented Cronbach's a value (Table 6) ranging from 0.57 to 0.91 for students and managers' responses. In both groups, the responses about the split cognitive style showed the highest mean (students, 3.67; managers, 3.61), followed by the systematic and intuitive cognitive style (students, 3.51 and 3.48; managers, 2.92 and 2.87), whereas integrated cognitive style and the undifferentiated cognitive style (students, 2.56 and 1.09; managers, 2.66 and 1.11) received the lowest mean. A major difference was observed regarding the managers' perceptions over the students' perceptions concerning the students' integrated cognitive style. In the case of the cognitive diversity style, managers' responses scored higher, most likely due 
to their experience and daily interaction with working groups other than hospitality students. Moreover, for the purpose of assessing the correlation between cognitive diversity styles, a linear equation model was developed. The latent independent variables were identified as followed: Split Style ( $\xi 1)$, Systematic Style ( $\xi 2)$, Intuitive Style ( $\xi 3)$, Integrated Style ( $(4)$, Undifferentiated Style ( $\xi 5)$, with service quality standards $(\eta 1)$ and performance standards $(\eta 2)$ as the latent dependent variables.

Table 6: Cronbach's Values, Parameter and Reliability Values

\begin{tabular}{|c|c|c|c|c|c|c|c|c|c|c|c|}
\hline \multirow[t]{2}{*}{$\begin{array}{c}\text { Cognitive } \\
\text { Style } \\
\text { (Observed } \\
\text { Variable) } \\
\end{array}$} & \multicolumn{2}{|c|}{ Mean } & \multicolumn{2}{|c|}{$\begin{array}{c}\text { Cronbach's } \\
\text { Values }\end{array}$} & \multicolumn{2}{|c|}{$\begin{array}{c}\text { Parameter } \\
\text { Value } \\
\text { (Estimated) }\end{array}$} & \multicolumn{2}{|c|}{$\begin{array}{c}\text { Reliability } \\
\text { (Individual } \\
\text { Item) }\end{array}$} & \multicolumn{2}{|c|}{$\begin{array}{l}\text { Reliability } \\
\text { (Latent } \\
\text { Variable) }\end{array}$} & \multirow[t]{2}{*}{ Latent Variable } \\
\hline & Stnts & Mgr & Stnts & Mgrs & Stnts & Mgrs & Stnts & Mgrs & Stnts & Mgrs & \\
\hline Intuitive & 3.48 & 2.87 & 0.79 & 0.75 & 0.85 & 0.83 & 0.74 & 0.72 & \multirow{2}{*}{0.7} & \multirow{2}{*}{0.92} & \multirow{2}{*}{$\begin{array}{l}\text { Service Quality } \\
\text { Standards in } \\
\text { Seasonal Hotels }\end{array}$} \\
\hline Integrated & 2.56 & 2.66 & 0.76 & 0.77 & 0.8 & 0.82 & 0.69 & 0.71 & & & \\
\hline Systematic & 3.51 & 2.92 & 0.84 & 0.82 & 0.93 & 0.88 & 0.82 & 0.77 & \multirow{2}{*}{0.68} & \multirow{2}{*}{0.87} & \multirow{2}{*}{$\begin{array}{l}\text { Organizational } \\
\text { Performance } \\
\text { Standards in } \\
\text { Seasonal Hotels }\end{array}$} \\
\hline Undifferen. & 1.09 & 1.11 & $0 . .57$ & 0.5 & 0.77 & 0.72 & 0.66 & 0.61 & & & \\
\hline Split & 3.67 & 3.61 & 0.91 & 0.89 & 0.94 & 0.9 & 0.83 & 0.79 & & & \\
\hline
\end{tabular}

The analysis of the findings through the linear structural equation model, using the LISREL8.52 software, concerning the contribution of the students' cognitive diversity styles on service quality and performance standards are presented in Table 6 . The values among the independent and dependent variables present path coefficients, and in the parenthesis, the t-values of coefficients are presented. The outcome from the analysis of the observed variables within the structural model of the students' cognitive diversity styles pinpointed their contribution to service quality and performance standards in seasonal hotels. The findings showed significant factor loadings, particularly for the dependent variables: a) Split Style, b) Systematic Style and c) Intuitive Style.

The coefficient values ranged from 0.81 to 0.92 and from 0.78 to 0.87 for students and managers, respectively, suggesting a favourable fitness range. Similarly, the t-values of measures were bigger than 1.93 and 1.88 (for students and managers), with the main exception being the Undifferentiated Cognitive Style that had a value 1.61 for students and 1.55 for managers. Therefore, the analysis of the values gave no significant error variances or negative error variance, designating a favourable model fitness. Also, the model fit indices [Table 7] indicate that the model fits the data, reflecting the values of the measures to have fulfilled ideal standards. In the next step, an internal structural fitness analysis was performed to examine the significance of the latent variable and the parameter value along with the reliability of the respective indicators [Table 6]. The analysis of the reliability factor gave values ranging from 0.66 to 0.83 and 0.61 to 0.79 for students and managers, respectively. The values of the latent variables ranged from 0.70 to 0.92 for students and from 0.68 to 0.87 for managers. All resulting values were found to be acceptable. 


\section{Table 7: Model fit indices}

\begin{tabular}{|l|l|}
\hline \multicolumn{1}{|c|}{ Model Fit Indices } \\
\hline \multicolumn{1}{|c|}{ Students } & \multicolumn{1}{c|}{ Managers } \\
\hline $\mathrm{x}^{2}$ ratio $=2.52 ; \mathrm{NFI}=0.91 ; \mathrm{RMSEA}=0.07 ; \mathrm{AGFI}=0.89$ & $\mathrm{x}^{2}$ ratio $=2.44 ; \mathrm{NFI}=0.89 ; \mathrm{RMSEA}=0.05 ; \mathrm{AGFI}=0.81$ \\
\hline $\mathrm{RMR}=0.05 ; \mathrm{PNFI}=0.79 ; \mathrm{PGFI}=0.66$ & $\mathrm{RMR}=0.04 ; \mathrm{PNFI}=0.72 ; \mathrm{PGFI}=0.61$ \\
\hline
\end{tabular}

Therefore, the analysis of the path coefficients between students and managers' latent variables alter Split, Systematic, Intuitive, and Integrated Cognitive Styles to have a significant impact on service quality standards and, thus, they have the biggest influence on organisational performance standards in seasonal hotels. Consequently, the study hypotheses H1a, H1b, H2, H3, H4 are accepted. Although Undifferentiated Cognitive Style had no significant influence on service quality or organisational performance standards, no positive associations were found with its contribution to seasonal hotels. As a result, the study hypotheses H5 and $\mathrm{H} 6$ are rejected.

\section{CONCLUSIONS}

The current study examined an important gap in the hospitality management literature concerning hospitality students' cognitive diversity style and its impact on service quality and organisational performance standards in seasonal hotels. It advances the field of deep-level diversity by making empirical contributions and setting the research framework conditions of the contribution of cognitive diversity; therefore, the study advances knowledge in hotel workforce diversity management. Also, the current study empirically improves the qualitative fulfilment of job vacancies in seasonal hotels. Hypotheses formulation and testing were based on three driving pillars. First, due to operational seasonality effects in hotels and the extensive requirements to fulfil vacancies with qualified and skilful labour to work on a seasonal basis (Australia Hotel Association, 2015; Chalkiti \& Sigala, 2010; Deloitte, 2015, 2017; Goh \& Lee, 2018; World Travel \& Tourism Council, 2017), an emerging reality alters the need to consider the quality contribution of hospitality students during summer internships or part-time employment (H1a, H1b, H2). Students' cognitive diversity style is emerging as a critical success factor in securing service quality and organisational performance in seasonal hotels (Brevis \& Vrba, 2015; Strydom \& Fourie, 2018). This was revealed by the statistical interpretation that indicated a dominant tendency of the split cognitive style on service quality and organisational performance standards (Table 5). Second, since hospitality students compose a respectful percentage of seasonal employees, higher education hospitality institutions and seasonal hotels should consider the dynamic potentials of students over other seasonal employees (H5, H6; Goh \& Lee, 2018). The aggregate values emerging from the responses of both groups (students and managers) underline the necessity for the involved stakeholders to reconsider and reform the educational, professional, and employment framework for students (Baum et al., 2016), considering as well the case of international students (Hadjioannou, 2019; Kathimerini, 2018). Third, the educational relatedness and professional preparedness of hospitality students, due to their educational background, offers a diversified pool of potential candidates to successfully fulfil open vacancies in the hotel industry (H3, H4; Cox \& Blake, 1991; Hoever et al., 2012; Menold \& Jablokow, 2019). The findings from the study clearly reveal a positive impact of cognitive diversity style on service quality and organisational 
performance standards in seasonal hotels (Manoharan et al., 2019; McMahon, 2011; Menold \& Jablokow, 2019; Singal, 2014). As a result, hospitality educational institutions and industry stakeholders should liaise to achieve a twofold purpose.

First is the introversion purpose that is reflected in the curriculum design of educational institutions, requiring a more comprehensive and skilful development of personality and professional virtues. Thus, the extroversion purpose sees the responsibility of seasonal hotel organisations to undertake the initiative to pursue and be engaged in an ongoing, long-term extra-curriculum cooperation with local educational institutions. Through pre-determined and frequent on-campus educational meetings, hotel organisations may nourish a purer and more clear professional direction for hospitality students, along with the seasonal job requirements and specifications. Hence, professional and organisational behavioural and psychographic elements may be impaired elements in the learning process. Such a multi-level and multi-dimensional approach could alter the infusion of industry experts' tacit cognition with the students' cognitive diversity style, creating in-class experiential simulations that ease the assimilation of new tacit knowledge. The major outcome here would be an early first job induction and orientation that enrich the dominating patterns of the particular cognitive style.

Also, it is pertinent to note the significant reliability and the effective contribution of hospitality students' cognitive diversity style on service quality and organisational performance standards of seasonal hotels. The findings support the main conclusions of the studies of Manoharan et al. (2019) and Menold \& Jablokow (2019) that support the positive relation of cognitive diversity towards quality standards and organisational performance. It seems that the multifaceted background of the Split Cognitive Style hosts a highly responsive professional dynamism and a competent individuality of hospitality students. These findings provide support for a well-balanced and relatively equal degree of using the Intuitive and Systematic Cognitive Style during service. As a result, hospitality students are able to consciously select a particular cognitive style, according to a given situation, deal with customers in order to proactively act or react, and meet expected standards. This is most likely an outcome emerging not only from individual personality traits but also from educational and work-related influences. This is observable and it is confirmed by the findings and the aggregate responses of both groups (students and managers). For example, managers, who have similar hospitality education and relevant professional working experience, may insist that hospitality students use similar approaches or processes in performing their jobrelated duties, increasing their job-fit level.

Therefore, hospitality students' cognitive diversity style is connected to a conscious-oriented, ordered, and rational approach in performing duties and responsibilities. The findings show that students as interns may use a sequential process of thinking in the service sequence process and in handling particular problems, due to their cognitive styles. These critical thinking and reflective virtues of the interns seem to lead to the development of more effective working groups within seasonal hotels, overcoming serious issues emerging from the operations of seasonal hotels. Thus, hospitality students' capability to employ different cognitive styles accordingly increases the possibilities to minimise any problems emerging from communication or work processes. This assists in developing a common working culture and becoming aware of non-verbal communication elements, 
which are useful in supporting service quality and performance. As a result, hospitality students understand the operational limitations and drawbacks, easing the creation of synergies in problem-solving, decision-making, and accomplishing high-productivity standards. Such synergies contribute positively as well to the hotel organisational system and culture by eliminating any employee misfits due to a professionally inherited ability for the students to change and adapt to guests' requests.

\section{IMPLICATIONS, LIMITATIONS, AND CONCLUDING REMARKS}

This study contributes to the literature on deep-level diversity by investigating hospitality students' cognitive diversity and its contribution to service quality and organisational performance standards in seasonal hotels. The findings of the study reveal a positive relation of hospitality students' cognitive diversity style to service quality and performance standards in seasonal hotels. These findings provide new practical and theoretical insights concerning deep-level diversity aspects in the hospitality industry. Existing research in hospitality did not reflect on deep-level diversity, instead of ascribing to surface-level diversity only. The results highlight a reliable source of human capital in effectively fulfilling job vacancies in seasonal hotels. Hospitality students' cognitive diversity style seems to be infused with the essential professional attributes to respond successfully to employability standards and requirements of seasonal hotels. Therefore, the findings from the CSI provide useful insights about the students' professional attributes, which can be used by seasonal hotels as a guide in recruiting hospitality students, thereby ensuring service quality and performance standards.

As with other research studies, certain limitations imply. Research findings may not be generalizable to other contexts due to their limitations in seasonal hotels. Thus, the quantitative nature of the current research inquiry allowed no opportunity to capture deeper meanings or interrelations related to the hospitality students' deep-level diversity emerging from their cognitive style. Another limitation of this study was its restriction to hospitality students and managers. Hospitality higher education institutions' input was examined in order to construct a comprehensive view of the interconnection between educational institutions and students' cognitive style. Therefore, future research could focus on a comparative study of hospitality students versus other types of seasonal employees in terms of service quality and performance reliability in hotels.

\section{REFERENCES}

Anastasiou, M., \& Koumi, I. (2019). Examining the Factors affecting students' perceptions and vocational program choices: A case study of the vocational and technical schools of Cyprus. The Cyprus Journal of Sciences, 17, 17-34.

Anglim, J., Sojo, V., Ashford, L. J., Newman, A., \& Marty, A. (2019). Predicting employee attitudes to workplace diversity from personality, values, and cognitive ability. Journal of Research in Personality, 83, 103865. https://doi.org/10.1016/j.jrp.2019.103865

Australia Hotel Association. (2015). Australian Hotels: Contributing to Economic Growth and National Prosperity. Taken on 12 Desember 2017, from https://issuu.com/australianhotelsassociation/docs/the_publication_2015.16

Baum, T., Kralj, A., Robinson, R. N. S., \& Solnet, D. J. (2016). Tourism workforce 
research: A review, taxonomy and agenda. Annals of Tourism Research, 60, 1-22. https://doi.org/10.1016/j.annals.2016.04.003

Brevis, T., \& Vrba, M. (2015). Contemporary Management Principles. Cape Town: Juta.

Bruner, J. S. (1966). Toward a theory of instruction. Cambridge: Belknap Press.

Caribbean Tourism Performance. (2017). CTO Caribbean Tourism Performance Report 2017. Caribbean.

CEDEFOP. (2019). Skill shortages and gaps in European enterprises: Striking a balance between vocational education and training and the labour market. $\begin{array}{lllll}\text { Taken } & \text { on } & 30 & \text { November } & \text { 2019, }\end{array}$ https://www.cedefop.europa.eu/files/3071_en.pd

Chalkiti, K., \& Sigala, M. (2010). Staff turnover in the Greek tourism industry. International Journal of Contemporary Hospitality Management, 22(3), 335359. https://doi.org/10.1108/09596111011035945

Cox, T. H., \& Blake, S. (1991). Managing cultural diversity: implications for organizational competitiveness. Academy of Management Perspectives, 5(3), 45-56. https://doi.org/10.5465/ame.1991.4274465

Deloitte. (2015). Australian Tourism Labour Force Report: 2015-2020 for Australian Trade Commission. Taken from https://www.tra.gov.au/ArticleDocuments/185/Australian_Tourism_Labour_ Force_FINAL.PDF.aspx? Embed=Y

Deloitte. (2017). The 2017 Deloitte Millennial Survey: Apprehensive Stability and Opportunities in an Uncertain World. Taken from https://www2.deloitte.com/content/dam/Deloitte/au/Documents/aboutdeloitte/

Duro, J. A., \& Turrión-Prats, J. (2019). Tourism seasonality worldwide. Tourism Management Perspectives, 31, 38-53. https://doi.org/10.1016/j.tmp.2019.03.010

Edwards, J. R., \& Lambert, L. S. (2007). Methods for integrating moderation and mediation: A general analytical framework using moderated path analysis. Psychological Methods, 12(1), 1-22. https://doi.org/10.1037/1082989X.12.1.1

Farh, J.-L., Lee, C., \& Farh, C. I. C. (2010). Task conflict and team creativity: A question of how much and when. Journal of Applied Psychology, 95(6), 11731180. https://doi.org/10.1037/a0020015

Ferrante, M., Lo Magno, G. L., \& De Cantis, S. (2018). Measuring tourism seasonality across European countries. Tourism Management, 68, 220-235. https://doi.org/10.1016/j.tourman.2018.03.015

Financial Mirror. (2019a). CYPRUS: Tourism headed for labour standoff as industrial peace jeopardised. Taken on 22 February 2020, from https://www.financialmirror.com/2019/07/27/cyprus-tourism-headed-forlabour-standoff-as-industrial-peace-jeopardised/

Financial Mirror. (2019b). ECONOMY: Cyprus labour shortages felt in key industries. Taken on 22 February 2020, from https://www.financialmirror.com/2019/07/06/economy-cyprus-labourshortages-felt-in-

Goh, E., \& Lee, C. (2018). A workforce to be reckoned with: The emerging pivotal Generation Z hospitality workforce. International Journal of Hospitality 
Management, 73, 20-28. https://doi.org/10.1016/j.ijhm.2018.01.016

Goh, E., \& Okumus, F. (2020). Avoiding the hospitality workforce bubble: Strategies to attract and retain generation $\mathrm{Z}$ talent in the hospitality workforce. Tourism Management Perspectives, 33, 100603. https://doi.org/10.1016/j.tmp.2019.100603

Gröschl, S. (2011). Diversity management strategies of global hotel groups. International Journal of Contemporary Hospitality Management, 23(2), 224 240. https://doi.org/10.1108/09596111111119347

Hadjioannou, B. (2019). Hotels, restaurants say face acute staff shortage. Taken on 15 November 2019, from Phileleptheros Newspaper website: https://incyprus.com/hotels-restaurants-say- face-acute-staff-shortage/

Hanaysha, J. (2016). Examining the Effects of Employee Empowerment, Teamwork, and Employee Training on Organizational Commitment. Procedia - Social and Behavioral Sciences, 229, 298-306. https://doi.org/10.1016/j.sbspro.2016.07.140

Hight, S. K., Gajjar, T., \& Okumus, F. (2019). Managers from "Hell" in the hospitality industry: How do hospitality employees profile bad managers? International Journal of Hospitality Management, 77, 97-107. https://doi.org/10.1016/j.ijhm.2018.06.018

Hoever, I. J., van Knippenberg, D., van Ginkel, W. P., \& Barkema, H. G. (2012). Fostering team creativity: Perspective taking as key to unlocking diversity's potential. Journal of Applied Psychology, 97(5), 982-996. https://doi.org/10.1037/a0029159

Hsiao, A., Ma, E., \& Auld, C. (2014). Organisational attractiveness in the Taiwanese hotel sector: Perceptions of indigenous and non-indigenous employees. Journal of Hospitality and Tourism Management, 21, 116-126. https://doi.org/10.1016/j.jhtm.2014.09.002

Kathimerini. (2018). Cyprus hotels in need of staff Hoteliers say foreign students from non-EU countries could be part of solution. Take on 20 December 2019, from https://knews.kathimerini.com.cy/en/business/cyprus-hotels-in-need-ofstaff

Kim, B. P., Murrmann, S. K., \& Lee, G. (2009). Moderating effects of gender and organizational level between role stress and job satisfaction among hotel employees. International Journal of Hospitality Management, 28(4), 612619. https://doi.org/10.1016/j.ijhm.2009.04.001

Kim, H. J., \& Agrusa, J. (2011). Hospitality service employees' coping styles: The role of emotional intelligence, two basic personality traits, and sociodemographic factors. International Journal of Hospitality Management, 30(3), 588-598. https://doi.org/10.1016/j.ijhm.2010.11.003

Kotey, B., \& Slade, P. (2005). Formal Human Resource Management Practices in Small Growing Firms*. Journal of Small Business Management, 43(1), 1640. https://doi.org/10.1111/j.1540-627X.2004.00123.x

KPMG. (2019). Cyprus Hospitality Report: Annual report outlining the key trends and major drivers of the Cyprus Hospitality Market. Taken on 15 January 2020, fom https://assets.kpmg/content/dam/kpmg/cy/pdf/2019/Cyprus Hospitality Report_1st-edition_Ju

Manoharan, A., Sardeshmukh, S. $\bar{R} .$, \& Gross, M. J. (2019). Informal diversity management practices and their effectiveness: In the context of ethnically 
diverse employees in hotels. International Journal of Hospitality Management, 82, 181-190. https://doi.org/10.1016/j.ijhm.2019.05.003

Manoharan, A., \& Singal, M. (2017). A systematic literature review of research on diversity and diversity management in the hospitality literature. International Journal of Hospitality Management, 66, 77-91. https://doi.org/10.1016/j.ijhm.2017.07.002

McKenney, J. L., \& Keen, P. W. (1974). How managers' minds work. Harvard Business Review.

McMahon, A. M. (2011). Does Workplace Diversity Matter? A Survey Of Empirical Studies On Diversity And Firm Performance, 2000-09. Journal of Diversity Management (JDM), 5(2). https://doi.org/10.19030/jdm.v5i2.808

Menold, J., \& Jablokow, K. (2019). Exploring the effects of cognitive style diversity and self-efficacy beliefs on final design attributes in student design teams. Design Studies, 60, 71-102. https://doi.org/10.1016/j.destud.2018.08.001

Mowforth, M., \& Munt, I. (1997). Tourism and sustainability: Development, globalisation and new tourism in the third world. United Kingdom: Routledge.

Pegg, S., Patterson, I., \& Gariddo, P. V. (2012). The impact of seasonality on tourism and hospitality operations in the alpine region of New South Wales, Australia. International Journal of Hospitality Management, 31(3), 659-666. https://doi.org/10.1016/j.ijhm.2011.09.001

Pinar, M., McCuddy, M. K., Birkan, I., \& Kozak, M. (2011). Gender diversity in the hospitality industry: An empirical study in Turkey. International Journal of Hospitality Management, 30(1), 73-81. https://doi.org/10.1016/j.ijhm.2010.06.007

Rousselet, G. A., Pernet, C. R., \& Wilcox, R. R. (2019). A practical introduction to the bootstrap: a versatile method to make inferences by using data-driven simulations. PsyArXiv.

Sauer, J., Felsing, T., Franke, H., \& Rüttinger, B. (2006). Cognitive diversity and team performance in a complex multiple task environment. Ergonomics, 49(10), 934-954. https://doi.org/10.1080/00140130600577502

Shin, S. J., Kim, T.-Y., Lee, J.-Y., \& Bian, L. (2012). Cognitive Team Diversity and Individual Team Member Creativity: A Cross-Level Interaction. Academy of Management Journal, 55(1), 197-212. https://doi.org/10.5465/amj.2010.0270

Singal, M. (2014). The business case for diversity management in the hospitality industry. International Journal of Hospitality Management, 40, 10-19. https://doi.org/10.1016/j.ijhm.2014.02.009

Sobel, M. E. (1982). Asymptotic confidence intervals for indirect effects in structural equation models. Washington DC: American Sociological Association.

Song, H. J., Yoon, Y. N., \& Kang, K. H. (2020). The relationship between board diversity and firm performance in the lodging industry: The moderating role of internationalization. International Journal of Hospitality Management, 86, 102461. https://doi.org/10.1016/j.ijhm.2020.102461

Sourouklis, C., \& Tsagdis, D. (2012). Workforce diversity and hotel performance: A systematic review and synthesis of the international empirical evidence. International Journal of Hospitality Management, 34, 394-403. 
https://doi.org/10.1016/j.ijhm.2012.11.013

Strydom, K., \& Fourie, C. J. S. (2018). The perceived influence of diversity factors on effective strategy implementation in a higher education institution. Heliyon, 4(4), e00604. https://doi.org/10.1016/j.heliyon.2018.e00604

Tekleab, A. G., \& Quigley, N. R. (2014). Team deep-level diversity, relationship conflict, and team members' affective reactions: A cross-level investigation. Journal of Business Research, 67(3), 394-402. https://doi.org/10.1016/j.jbusres.2012.12.022

Tufan, P., \& Wendt, H. (2020). Organizational identification as a mediator for the effects of psychological contract breaches on organizational citizenship behavior: Insights from the perspective of ethnic minority employees. European Management Journal, 38(1), 179-190. https://doi.org/10.1016/j.emj.2019.07.001

Wang, X.-H. (Frank), Kim, T.-Y., \& Lee, D.-R. (2016). Cognitive diversity and team creativity: Effects of team intrinsic motivation and transformational leadership. Journal of Business Research, 69(9), 3231-3239. https://doi.org/10.1016/j.jbusres.2016.02.026

Wen, J., Huang, S. (Sam), \& Hou, P. (2019). Emotional intelligence, emotional labor, perceived organizational support, and job satisfaction: A moderated mediation model. International Journal of Hospitality Management, 81, 120130. https://doi.org/10.1016/j.ijhm.2019.01.009

Witkin, H. A., Dyk, R. B., Patterson, H. F., Goodenough, D. R., \& Karp, S. A. (1962). Psychological differentiation. New York: John Wiley.

Witkin, H. A., Lewis, H. B., Hertzman, M., Machover, K., Meissner, P. B., \& Wapner, S. (1951). Personality through perception: An experimental and clinical study. New York: Harper and Row.

World Travel \& Tourism Council. (2017). Travel and Tourism Global Economic Impact and Issues $2017 . \quad$ https://www.wttc. org//media/files/reports/economic-impact-research/2017documents/globaleconomic-impact-and-issues-2017.pdf.

Young, A. T., \& Tackett, M. Y. (2018). Globalization and the decline in labor shares: Exploring the relationship beyond trade and financial flows. European Journal of Political Economy, 52, 18-35. https://doi.org/10.1016/j.ejpoleco.2017.04.003 